\title{
A case of minimal change disease after the administration of anti receptor activator of nuclear factor kappa $B$ ligand (RANKL) monoclonal antibody: a case report
}

Keisuke Horikoshi ${ }^{1}$, Norihiko Sakai ${ }^{1,2^{*}}$ (D, Naoki Yamamoto ${ }^{1}$, Hisayuki Ogura ${ }^{1}$, Koichi Sato ${ }^{1}$, Taro Miyagawa ${ }^{1}$, Shinji Kitajima', Tadashi Toyama', Akinori Hara', Yasunori Iwata', Miho Shimizu', Kengo Furuichi ${ }^{3}$ and Takashi Wada'

\begin{abstract}
Background: Minimal change disease (MCD) is one of the causes of idiopathic nephrotic syndrome in adults. The pathogenesis of proteinuria in MCD has not been fully understood. Recently, it has been reported that the receptor activator of nuclear factor-kappa B (RANK)/RANK ligand (RANKL) may contribute to the podocyte biology in kidney diseases. Denosumab is a human anti-RANKL monoclonal antibody used to treat osteoporosis. Here we report a case of MCD after denosumab administration.

Case presentation: A 59-year-old male without any episodes of proteinuria was given denosumab to treat osteoporosis. Two weeks after its administration, he noticed a foamy urine and bilateral pretibial edema. Laboratory tests revealed that he had severe proteinuria $(15 \mathrm{~g} / \mathrm{g} \mathrm{Cr}$ ), hypoproteinemia $(4.0 \mathrm{~g} / \mathrm{dL})$, and hypoalbuminemia $(1.5 \mathrm{~g} /$ $\mathrm{dL}$ ). Based on the results, he was diagnosed with nephrotic syndrome. The proteinuria selectivity index was 0.05 , indicating selective proteinuria. Renal biopsy showed minor glomerular abnormality with less tubulointerstitial damage, and electron microscopy showed extensive foot process effacement, indicating MCD. With all these results, glucocorticoid therapy of $50 \mathrm{mg} /$ day prednisolone was started. After 4 weeks of treatment, the urinary protein level remains high $(3.1 \mathrm{~g} / \mathrm{g} \mathrm{Cr}$ ). Prednisolone therapy was continued, and the levels of proteinuria decreased gradually to the range of partial remission $(1.2 \mathrm{~g} / \mathrm{g} \mathrm{Cr})$ with another 7 weeks of prednisolone treatment, but complete remission was not achieved.
\end{abstract}

Conclusions: This might be a case wherein RANKL inhibition is associated with the pathogenesis of MCD. Further studies will be needed to elucidate the causal relationship of RANK-RANKL signaling to the pathogenesis of MCD.

Keywords: Minimal change disease, Nephrotic syndrome, RANK, RANKL, Case report

\footnotetext{
* Correspondence: norin0826@yahoo.co.jp

${ }^{1}$ Department of Nephrology and Laboratory Medicine, Institute of Medical,

Pharmaceutical and Health Sciences, Kanazawa University, 13-1 Takaramachi,

Kanazawa, Ishikawa 920-8641, Japan

${ }^{2}$ Division of Blood Purification, Kanazawa University Hospital, 13-1

Takaramachi, Kanazawa, Ishikawa 920-8641, Japan

Full list of author information is available at the end of the article
}

(c) The Author(s). 2020 Open Access This article is licensed under a Creative Commons Attribution 4.0 International License, which permits use, sharing, adaptation, distribution and reproduction in any medium or format, as long as you give appropriate credit to the original author(s) and the source, provide a link to the Creative Commons licence, and indicate if changes were made. The images or other third party material in this article are included in the article's Creative Commons licence, unless indicated otherwise in a credit line to the material. If material is not included in the article's Creative Commons licence and your intended use is not permitted by statutory regulation or exceeds the permitted use, you will need to obtain permission directly from the copyright holder. To view a copy of this licence, visit http://creativecommons.org/licenses/by/4.0/ The Creative Commons Public Domain Dedication waiver (http://creativecommons.org/publicdomain/zero/1.0/) applies to the data made available in this article, unless otherwise stated in a credit line to the data. 


\section{Background}

Minimal change disease (MCD) is one of the causes of idiopathic nephrotic syndrome in adults, accounting for approximately $10-15 \%$ of all cases $[1,2]$. Most of them respond to steroid treatment, so it has been called steroidsensitive nephrotic syndrome. However, the response rate in adults is lower, with $5-30 \%$ of MCD adult patients not responding to initial steroid therapy $[3,4]$. The pathogenesis of proteinuria in MCD has not been fully understood. Recently, it has been reported that podocytes play a key role in the mechanism of proteinuria.

The receptor activator of nuclear factor-kappa B (RANK) and its ligand RANKL are important regulators of bone mineral density [5]. RANK/RANKL is expressed not only in bone marrow-derived cells but also in non-bone marrow-derived cells such as skin epithelial cells, mammary epithelial cells, and renal glomeruli [6-10]. However, the precise role of RANK/ RANKL signaling has not been known in proteinuric kidney diseases.

Denosumab is a human anti-RANKL monoclonal antibody used to treat osteoporosis [11]. Here we report a case of MCD after denosumab administration. MCD has not been reported as a side effect of denosumab.

\section{Case presentation}

A 59-year-old male with a history of dyslipidemia and without any episodes of proteinuria was diagnosed with osteoporosis when he had knee bone fracture, the cause of which was suspected to be hypogonadotropic hypogonadism due to lower levels of luteinizing hormone, follicle-stimulating hormone, and testosterone. Other pituitary hormones were normal, with the magnetic resonance imaging showing a normal pituitary gland. He did not want to receive androgen replacement therapy, so denosumab with eldecalcitol was given to treat osteoporosis. Two weeks after its administration, he noticed a foamy urine and bilateral pretibial edema, which did not improve spontaneously. Two weeks later, he was admitted to the previous hospital, and laboratory tests showed that he had severe proteinuria $(15 \mathrm{~g} / \mathrm{g} \mathrm{Cr})$ and hypoalbuminemia $(1.5 \mathrm{~g} / \mathrm{dL})$. Based on the results, he was diagnosed with nephrotic syndrome. He was then referred to our hospital for further examination and treatment.

Upon admission to our hospital, his height and body weight were $170 \mathrm{~cm}$ and $65.0 \mathrm{~kg}$, respectively, and his blood pressure, heart rate, and body temperature were $150 / 86 \mathrm{mmHg}, 90 \mathrm{bpm}$, and $36.3^{\circ} \mathrm{C}$, respectively. Physical examination revealed bilateral pretibial pitting edema. Laboratory data for urine tests were as follows (normal ranges in parentheses): protein levels $11.7 \mathrm{~g} / \mathrm{g} \mathrm{Cr}(<0.15)$, occult blood $3+(-)$, red blood cells 10-19 /high power field $(<5)$. The proteinuria selectivity index was 0.05 , indicating selective proteinuria. Serum examination findings were as follows (normal ranges in parentheses): urea nitrogen $15 \mathrm{mg} /$ $\mathrm{dL}$ (7-23), serum creatinine $0.61 \mathrm{mg} / \mathrm{dL}(0.6-1.0)$, total protein $4.0 \mathrm{~g} / \mathrm{dL}$ (6.7-8.3), serum albumin $1.5 \mathrm{~g} / \mathrm{dL}$ (4.0-5.0), total cholesterol 376mg/dL (128-219), triglyceride $277 \mathrm{mg} / \mathrm{dL}$ (30-149), HDL cholesterol $50 \mathrm{mg} / \mathrm{dL}$ (40-99), LDL cholesterol $271 \mathrm{mg} / \mathrm{dL} \quad(40-$ 119), C-reactive protein $1.0 \mathrm{mg} / \mathrm{dL}(<0.3)$, IgG $453 \mathrm{mg} /$ dL (870-1700), IgA 299mg/dL (110-410), IgM 67mg/ $\mathrm{dL}(33-190)$, and $\mathrm{IgE} 147 \mathrm{IU} / \mathrm{mL}(<250)$. Antinuclear antibody, PR3-ANCA, MPO-ANCA, and anti-GBM antibody were not detected (Table 1). Chest X-ray showed neither cardiac dilatation, pleural fluid nor abnormal shadow. The electrocardiogram showed a left axis deviation. Computed tomography showed a normal-sized kidney with a smooth surface and no mass. Gastrointestinal endoscopy showed no tumor lesion.

Upon admission, we started telmisartan treatment ( $40 \mathrm{mg} /$ day), but the level of proteinuria was not reduced. On the 7th day of admission, renal biopsy was performed to identify the cause of nephrotic syndrome. Light microscopy showed minor glomerular abnormality with less tubulointerstitial damage (Fig. 1a), immunofluorescence studies showed no deposition (Fig. 1b), and electron microscopy showed extensive foot process effacement (Fig. 1c). From these findings and clinical course, he was diagnosed with MCD. To check the glomerular expression of RANK, we tried immunostaining by anti-RANK antibody. However, it was technically difficult because there was not enough amount of section left for immunostaining.

With all these results, glucocorticoid therapy of $50 \mathrm{mg} /$ day prednisolone was started. After 4weeks of treatment, the urinary protein level remains high $(3.1 \mathrm{~g} / \mathrm{g} \mathrm{Cr})$. Therefore, $150 \mathrm{mg} /$ day cyclosporine was added but terminated due to liver damage. Prednisolone therapy was continued, and the levels of proteinuria decreased gradually to the range of partial remission $(1.2 \mathrm{~g} / \mathrm{g} \mathrm{Cr})$ with another 7 weeks of prednisolone treatment (Fig. 2).

\section{Discussion and conclusions}

A 59-year-old male developed nephrotic syndrome within 2 weeks after denosumab administration. From the clinical course and renal biopsy, he was diagnosed with MCD. Even with the glucocorticoid treatment, he could not achieve complete remission. We speculated that RANKL inhibition by denosumab might be involved in the onset of steroid-resistant nephrotic syndrome. 
Table 1 Laboratory data on admission

Urinalysis
Protein
Selectivity Index
Occult blood
RBC
WBC
Squamous cell
Transitional cell
Tubular epithelial cell
Hyaline cast
Epithelial cast
Granular cast
Waxy cast
Fatty cast
RBC cast
WBC cast

\section{Blood count}

WBC

RBC

$\mathrm{Hb}$

$\mathrm{Ht}$

Plt

\section{Biochemical test}

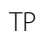

Alb

AST

ALT

LD

$\gamma$-GTP

ALP

T-Bil

CK

UN

$\mathrm{Cr}$

UA

$\mathrm{Na}$

K

$\mathrm{Cl}$

$\mathrm{Ca}$

IP

BS

$\mathrm{HbA} 1 \mathrm{c}$

T-Cho

TG

HDL-Cho

\section{7}

0.05

10-19

$1-4$

$<1$

$(-)$

5-9

$1+$

$1+$

$(-)$

$(-)$

$(-)$

$(-)$

$(-)$

$7.60 \times 10^{3}$

$4.27 \times 10^{6}$

12.7

37.8

$19.5 \times 10^{4}$

4.0

1.5

22

13

290

26

245

0.3

164

15

0.61

7.1

143

3.5

113

6.7

2.5

131

5.3

376

277

50
Table 1 Laboratory data on admission (Continued)

Immunological test

\begin{tabular}{|c|c|c|c|}
\hline \multirow[t]{3}{*}{$\mathrm{g} / \mathrm{g} \mathrm{Cr}$} & CRP & 1.0 & $\mathrm{mg} / \mathrm{dL}$ \\
\hline & $\lg G$ & 453 & $\mathrm{mg} / \mathrm{dL}$ \\
\hline & $\lg A$ & 299 & $\mathrm{mg} / \mathrm{dL}$ \\
\hline /HPF & $\lg M$ & 67 & $\mathrm{mg} / \mathrm{dL}$ \\
\hline /HPF & $\lg E$ & 147 & $\mathrm{IU} / \mathrm{mL}$ \\
\hline \multirow[t]{2}{*}{ /HPF } & C3 & 137 & $\mathrm{mg} / \mathrm{dL}$ \\
\hline & C4 & 41 & $\mathrm{mg} / \mathrm{dL}$ \\
\hline \multirow[t]{9}{*}{ /HPF } & $\mathrm{CH} 50$ & 60 & \\
\hline & ANA & $(-)$ & \\
\hline & MPO-ANCA & $<1.0$ & $\mathrm{U} / \mathrm{mL}$ \\
\hline & PR3-ANCA & $<1.0$ & $\mathrm{U} / \mathrm{mL}$ \\
\hline & GBM & $<2.0$ & $\mathrm{U} / \mathrm{mL}$ \\
\hline & \multicolumn{3}{|l|}{ Infection } \\
\hline & $\mathrm{HBs}-\mathrm{Ag}$ & $(-)$ & \\
\hline & HBs-Ab & $(-)$ & \\
\hline & $\mathrm{HBc}-\mathrm{Ab}$ & $(-)$ & \\
\hline$/ \mu \mathrm{L}$ & HCV-Ab & $(-)$ & \\
\hline
\end{tabular}

$/ \mu \mathrm{L}$

$\mathrm{g} / \mathrm{dL}$

$\%$

$/ \mu \mathrm{L}$

RANK and RANKL are important regulators of bone mineral density. RANK/RANKL signaling activates a variety of downstream signaling pathways required for osteoclast development, such as nuclear factor-kappa B (NF-B), mitogen-activated protein $\mathrm{g} / \mathrm{dL}$ kinase, and nuclear factor of activated $\mathrm{T}$ cells g/dL calcineurin-dependent 1 (NFATc1) [12, 13]. RANK/ IU/L RANKL is expressed not only in bone marrowTU/L derived cells but also in non-bone marrow-derived IU/L cells including podocytes [6-10]. RANK/RANKL ex$I U / L$ pression in podocytes has increased in puromycin amiIU/L nonucleoside nephrosis (PAN), a rat model of podocyte IU/L injury and human kidney diseases, such as IgA ne$\mathrm{mg} / \mathrm{dL}$ phropathy, membranous nephropathy, and focal segIU/L mental glomerulosclerosis (FSGS) [10]. In PAN rat $\mathrm{mg} / \mathrm{dL}$ model, the level of apoptosis of podocytes was also in$\mathrm{mg} / \mathrm{dL}$ creased in RANK knockdown by RANK siRNA and was protected by exogenous RANKL exposure, indicating $\mathrm{mg} / \mathrm{dL}$ that RANK/RANKL signaling may function as the sur$\mathrm{mEq} / \mathrm{L}$ vival signal for podocytes in PAN [10]. On the other $\mathrm{mEg} / \mathrm{L}$ hand, lithium chloride intervention attenuated urinary $\mathrm{mEq} / \mathrm{L}$ protein and histopathological change by reducing the $\mathrm{mg} / \mathrm{dL}$ levels of RANK, RANKL, and NF-B [14]. In addition to $\mathrm{mg} / \mathrm{dL}$ that, Chen et al. reported that RANK and RANKL were $\mathrm{mg} / \mathrm{dL}$ overexpressed in the kidneys of $\mathrm{db} / \mathrm{db}$ mice, a type 2 $\mathrm{mg} / \mathrm{dL}$ diabetic nephropathy model, and irbesartan also attenu$\% \quad$ ated urinary protein by downregulating RANK/RANKL $\mathrm{mg} / \mathrm{dL} \quad$ signaling and downstream NF-B pathway [15]. In this $\mathrm{mg} / \mathrm{dL} \quad$ case, we tried immunostaining by anti-RANK antibody $\mathrm{mg} / \mathrm{dL}$ to elucidate the contribution of RANK/RANKL signaling. However, it was technically difficult because there 
(a)

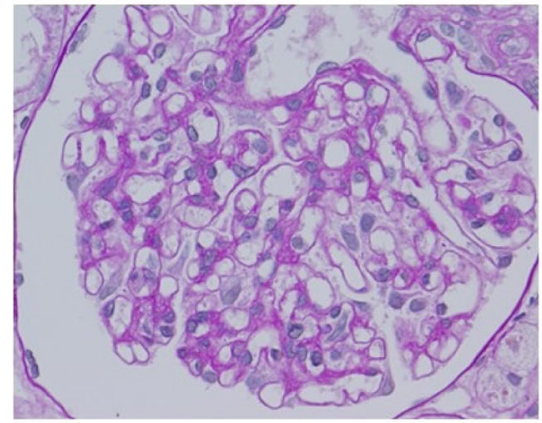

(b)
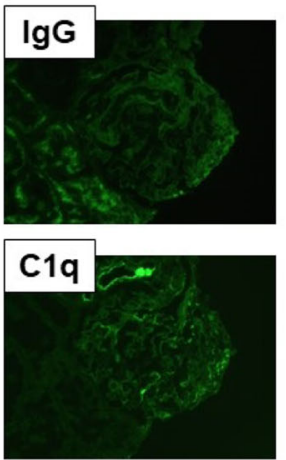
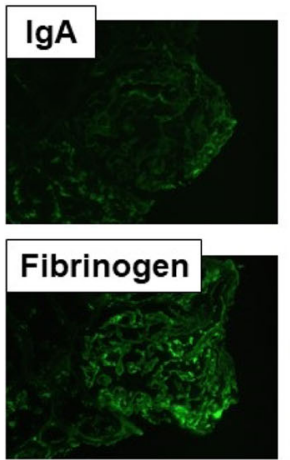

(c)

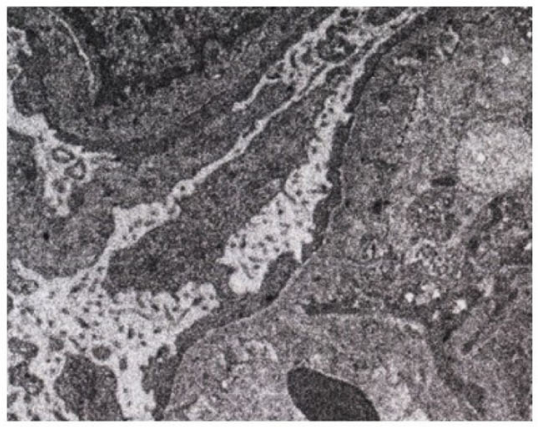

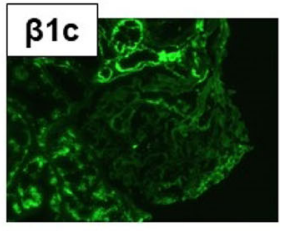
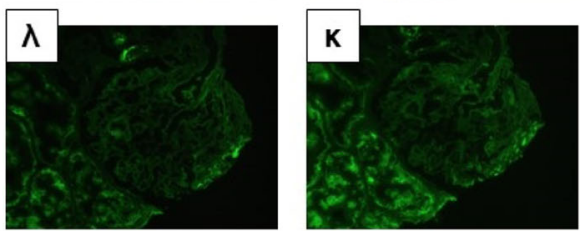

Fig. 1 Histopathological images of renal biopsy. a Light microscopy showed minor glomerular abnormality with less tubulointerstitial damage (PAS staining×400). b Immunofluorescence studies showed no deposition. c Electron microscopy showed extensive foot process effacement

was not enough amount of section left for immunostaining. With these results, RANK/RANKL signaling may have some contribution to the pathogenesis of proteinuric kidney diseases including MCD. To clarify the precise mechanisms of RANK/RANKL signaling in kidney diseases, further studies will be required.
Furthermore, regular follow-up of urine test may be needed when denosumab is administered for osteoporosis in patients with existing renal disease and CKD.

As described above, this case showed sustained proteinuria even after steroid and cyclosporine treatment. In a previous report, the observed median $\mathrm{T}$ max was 10days, and

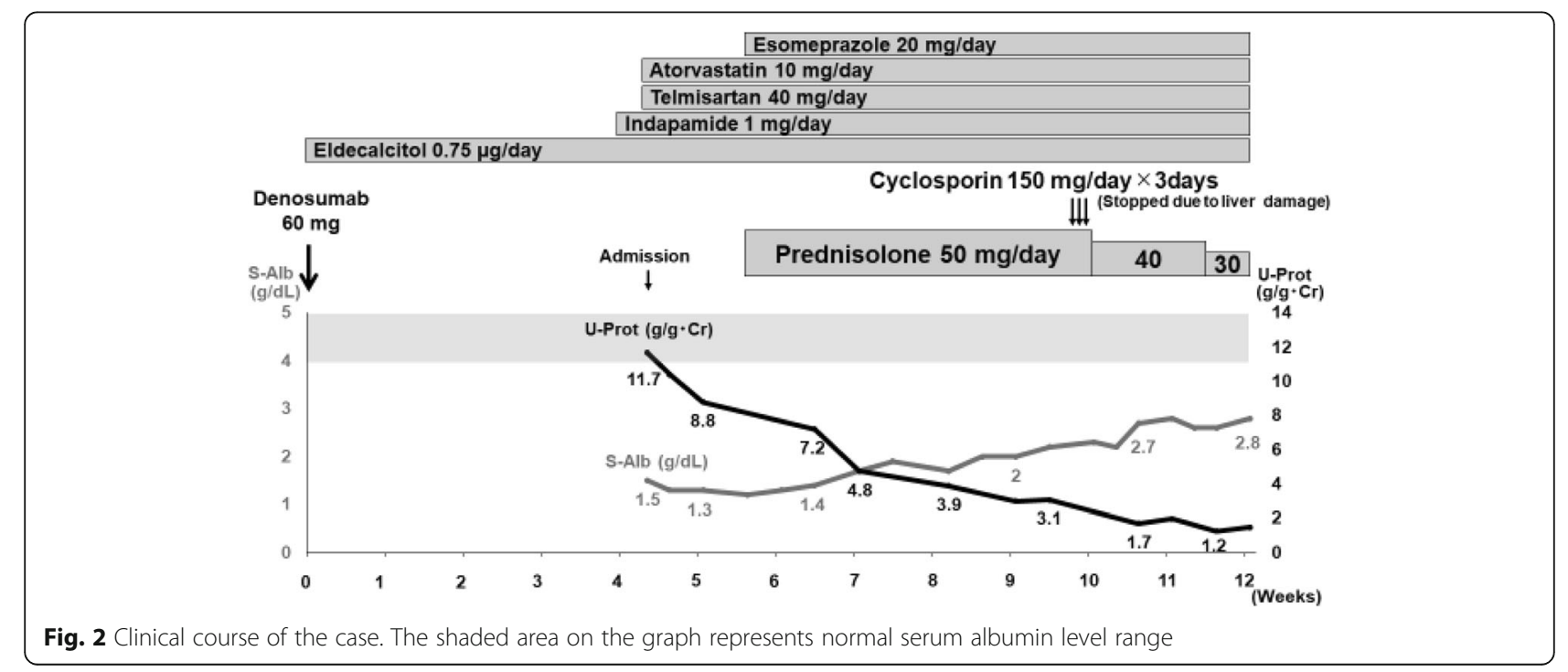


$\mathrm{T} 1 / 2$ was 25.4 days following the administration of $60 \mathrm{mg}$ denosumab [16-18]. Therefore, the extended half-life of denosumab might cause a continuous decline of survival signal in podocytes, resulting in persistent proteinuria in this case. Additionally, because it is sometimes difficult to distinguish between MCD and FSGS, this case may have been FSGS. The accumulation of cases of nephrotic syndrome after denosumab treatment will be required to evaluate the association of RANK/RANKL signaling with treatment resistance in nephrotic syndrome.

In summary, the case of MCD after denosumab administration might be associated with RANKL inhibition. Further studies will be needed to elucidate the causal relationship of RANK/RANKL signaling and the pathogenesis of MCD.

\section{Abbreviations}

MCD: Minimal change disease; RANK: Receptor activator of nuclear factorkappa B; RANKL: Receptor activator of nuclear factor-kappa B ligand; NFB: Nuclear factor- kappa B; NFATc1: Nuclear factor of activated T cells calcineurin-dependent 1; PAN: Puromycin aminonucleoside nephrosis; FSGS: Focal segmental glomerulosclerosis

\section{Acknowledgements}

Not applicable.

\section{Authors' contributions}

All authors made substantial contributions to the acquisition and interpretation of data, critical revision of the manuscript for important intellectual content, and approved the final version for publication. $\mathrm{KH}$, NS and TW made substantial contributions to the conception of this report. NY, $\mathrm{HO}, \mathrm{KS}, \mathrm{TM}, \mathrm{SK}, \mathrm{TT}, \mathrm{AH}, \mathrm{YI}, \mathrm{MS}, \mathrm{KF}$ performed the treatment. All authors read and approved the final manuscript.

\section{Funding}

There was no funding received for this manuscript.

\section{Availability of data and materials}

Not applicable.

\section{Ethics approval and consent to participate}

Written informed consent was obtained from the patient of this case report.

\section{Consent for publication}

Written informed consent was obtained from the patient for publication of case report and any accompanying images. A copy of the consent form is available for review and can be provided on request.

\section{Competing interests}

The authors declare that they have no competing interests.
2. Cameron JS. The nephrotic syndrome and its complications. Am J Kidney Dis. 1987;10:157-71

3. Zhao L, Cheng J, Zhou J, Wu C, Chen J. Enhanced steroid therapy in adult minimal change Nephrotic syndrome: a systematic review and metaanalysis. Intern Med. 2015;54:2101-8.

4. Nakayama M, Katafuchi R, Yanase T, Ikeda K, Tanaka H, Fujimi S. Steroid responsiveness and frequency of relapse in adult-onset minimal change nephrotic syndrome. Am J Kidney Dis. 2002;39:503-12.

5. Yasuda $H$, Shima N, Nakagawa $N$, et al. Osteoclast differentiation factor is a ligand for osteoprotegerin/osteoclastogenesis-inhibitory factor and identical to TRANCE/RANKL. Proc Natl Acad Sci U S A. 1998;95:3597-602.

6. Duheron $\mathrm{V}$, Hess $\mathrm{E}$, Duval M, et al. Receptor activator of NF-kappa B (RANK) stimulates the proliferation of epithelial cells of the epidermo-pilosebaceous unit. Proc Natl Acad Sci U S A. 2011;108:5342-7.

7. Fata JE, Kong YY, Li J, et al. The osteoclast differentiation factor osteoprotegerin-ligand is essential for mammary gland development. Cell. 2000;103:41-50

8. Beleut M, Rajaram RD, Caikovski M, et al. Two distinct mechanisms underlie progesterone-induced proliferation in the mammary gland. Proc Natl Acad Sci US. 2010;107:2989-94.

9. Kartsogiannis $\mathrm{V}$, Zhou H, Horwood NJ, et al. Localization of RANKL (receptor activator of NF kappa B ligand) mRNA and protein in skeletal and extraskeletal tissues. Bone. 1999;25:525-34.

10. Liu S, Shi W, Xiao H, et al. Receptor activator of NF-kappaB and podocytes: towards a function of a novel receptor-ligand pair in the survival response of podocyte injury. PLoS One. 2012;7:e41331.

11. Bekker PJ, Holloway DL, Rasmussen AS, et al. A single-dose placebocontrolled study of AMG 162, a fully human monoclonal antibody to RANK L, in postmenopausal women. J Bone Miner Res. 2004;19:1059-66.

12. Wada T, Nakashima T, Hiroshi N, Penninger JM. RANKL-RANK signaling in osteoclastogenesis and bone disease. Trends Mol Med. 2006;12:17-25.

13. Boyce BF, Xing L. Biology of RANK, RANKL, and osteoprotegerin. Arthritis Res Ther. 2007;9(Suppl 1):S1.

14. Zhou YX, Shi LX, Yang $H$, et al. Effects of a GSK- $3 \beta$ inhibitor on the renal expression levels of RANK, RANKL and NF- $B$ in a rat model of diabetic nephropathy. Exp Ther Med. 2016;11:2495-502.

15. Chen XW, Du XY, Wang YX, et al. Irbesartan ameliorates diabetic nephropathy by suppressing the RANKL-RANK-NF- B pathway in type 2 diabetic $\mathrm{db} / \mathrm{db}$ mice. Mediat Inflamm. 2016. https://doi.org/10.1155/2016/1405924.

16. Chen Q, Hu C, Liu Y, et al. Pharmacokinetics, pharmacodynamics, safety, and tolerability of single-dose denosumab in healthy Chinese volunteers: a randomized, single-blind, placebo-controlled study. PLoS One. 2018;13: e0197984.

17. Prolia (denosumab) injection [prescribing information]. Amgen Inc, Thousand Oaks. 2015. http://www.accessdata.fda.gov/drugsatfda_docs/ label/2015/125320s174lbl.pdf. Accessed 25 Jan 2016.

18. Xgeva (denosumab) injection [prescribing information]. Amgen Inc, Thousand Oaks. 2015. http://www.accessdata.fda.gov/drugsatfda_docs/ label/2015/125320s168lbl.pdf. Accessed 25 Jan 2016

\section{Publisher's Note}

Springer Nature remains neutral with regard to jurisdictional claims in published maps and institutional affiliations.

\section{Ready to submit your research? Choose BMC and benefit from:}

- fast, convenient online submission

- thorough peer review by experienced researchers in your field

- rapid publication on acceptance

- support for research data, including large and complex data types

- gold Open Access which fosters wider collaboration and increased citations

- maximum visibility for your research: over $100 \mathrm{M}$ website views per year

At $\mathrm{BMC}$, research is always in progress.

Learn more biomedcentral.com/submissions

\section{References}

1. Vivarelli M, Massella L, Ruggiero B, Emma F. Minimal change disease. Clin J Am Soc Nephrol. 2017;12:332-45. 